\title{
Mainmast \\ Speaks: \\ The paintings \\ of Pauline \\ Thompson
}

This paper explores the work of Pauline Thompson (1942-2012), an Auckland based artist who painted throughout her adult life. Although she received local critical acclaim for her work in a 'Pop Art Idiom' in the 1960s, as Pauline's work shifted to a more 'metaphysical' style she arguably became less fashionable. This paper considers the reception of her work by art critics, the context in which she was creating her work, and the general discourse of art critics in Aotearoa over the period of her career. Pauline's own writings and discourse on her practice are interpolated into the discussion. This paper was first presented at the conference of PHANZA (Professional Historians Aotearoa New Zealand Association) in 2019, and following feedback, has been developed into this article. The author knew Pauline Thompson personally, and interweaves informal discussions she had with the painter into this narrative.

Keywords: \#feminist theory \#art history \#women artists \#pacific \#painting, \#oceania \#Mutiny on the Bounty \#reception studies 


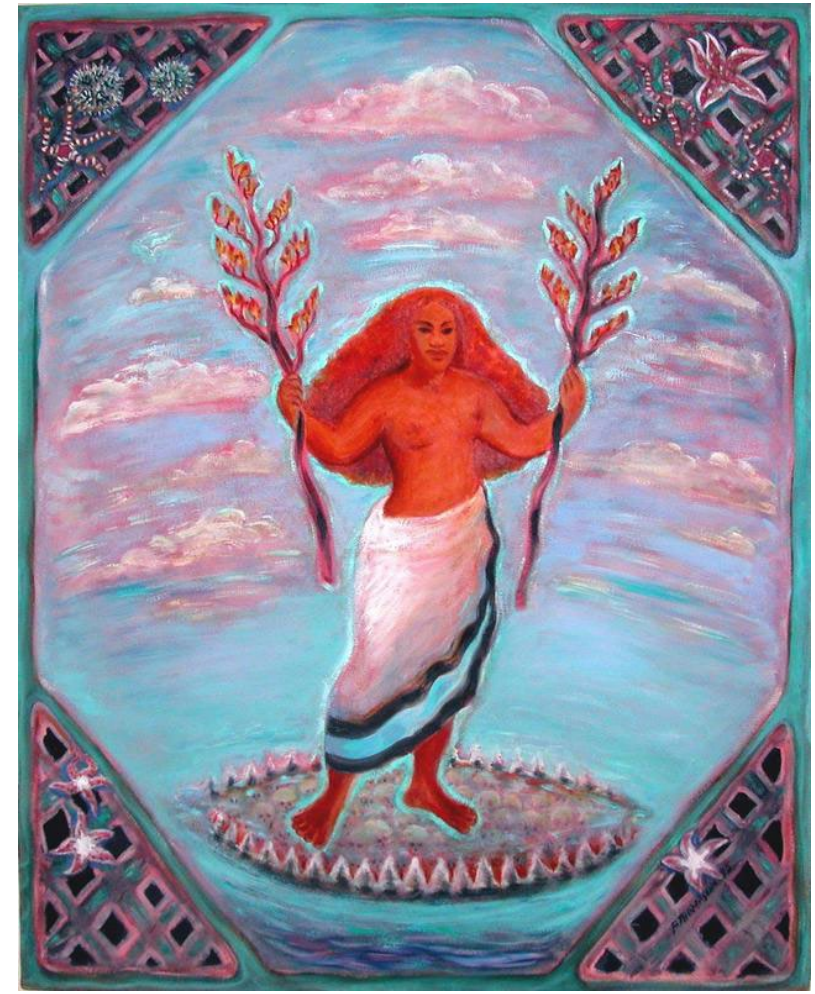

Figure 1. 'Moana Nui', Pauline Thompson (1995), 770 × 610mm, James Wallace Trust Art Collection reproduced with permission $=$ detail\&page $=1$ \&id $=14235 \& \mathrm{db}=$ object

Pauline Adele Thompson was born in 1942 and died in 2012. She lived in Auckland throughout her life and was descended from Mauatua, nicknamed 'Mainmast' by the men of the Mutiny of the Bounty. Mauatua was the daughter of Tu, the paramount chief of Tahiti and the wife of Fletcher Christian, the leader of the mutiny on the ship the Bounty on April 28, 1789. Pauline painted throughout her adult life and was often referred to as a 'metaphysical painter' by critics. She lived on the North Shore of Auckland and was the sole parent of three children after the breakup of her marriage in the 1980s to fellow artist Ross Ritchie. Although featuring in many exhibitions of the 1960s and 1970s, Pauline's work became less fashionable in the 1980s as she moved away from the pop art aesthetic for which she was noted in the 1960s. Exploring themes of reproduction, women's life narratives and the story of the Mutiny of the Bounty and Pacific mythic themes, her later paintings were not widely celebrated in the world of art criticism though they were exhibited at various galleries in New Zealand, Australia and the South Pacific (particularly Norfolk Island) and her work is held at the Auckland Art Gallery and the James Wallace collection. This paper suggests that Pauline's work deserves consideration outside the trends of art criticism.

\section{NZ WOMEN PAINTERS}

In 1975, Auckland Art Gallery opened an exhibition of NZ Women Painters. The exhibition catalogue stated:

These are not Sunday painters, dabbling in art in the midst of domestic duties, but professionals, professionally trained and devoting their life to their art. Yet they are not the ardent spinsters, beloved of the myth-maker; many married, many have children.

In the year this exhibition opened, Pauline Adele Thompson was in the midst of domestic duties. Married to the painter Ross Ritchie who was the typesetter and designer for the NZ Women Painters exhibition catalogue, Pauline and he were raising 3 children under the age of six. She was not included in this exhibition at Auckland Art Gallery. However, her work was already well thought of. During the 1960s, Pauline was embraced as one of the up and coming young artists, being, as art critic Anne Kirker later wrote, 'virtually the only woman mentioned in Gordon Brown and Hamish Keith's influential book "An Introduction to New Zealand Painting 1839-1967" as being among the new generation of painters emerging at that time'. Yet as Pauline described it in later life, she was beginning to resist maintaining her place in the dominant modernist ideology. Some of this was in her control, in terms of the subjects she chose and the style in which she painted. But she realised much of her experience was also gendered - she was treated differently than contemporary male artists.

Pauline Thompson had her work first displayed in 1959 and had subsequently attended Elam School of Fine Art in Auckland during 1963 and 1964. Colin McCahon and Garth Tapper were her tutors. In 1997, Megan Corbett wrote that in the 1960s Thompson 'worked in a Pop Art idiom in conjunction with her husband. After the breakup of this relationship her work took a more serious and metaphysical aspect'.

Pauline's attendance at Elam School of Fine Arts was in itself an accomplishment at a time when only 50 or so students were accepted into art school in each cohort (compare this with about 4 to 500 students 
in the degree and masters programmes today). It is often mentioned by writers of Pauline's biographical notes that Colin McCahon, indisputably the king of the New Zealand art canon for many years, was her tutor. Unrecorded in the official biographical notes, is that while she was his student, McCahon told her that as a woman she would never be a real artist, because she would have children and be distracted from her calling. Pauline told the author she quit Elam because of this conversation.

In her memoir painter Jacqueline Fahey, an artist a little older than Pauline, recalled in 1956 spending time with artists and writers such as Bruce Mason, James K Baxter and Louis Johnson when she was working at Harry's Café, above Parsons Bookshop at 126 Lambton Quay, Wellington. She described the male artists' behaviour and attitudes towards women:

It was clear that the arts, at that time, were a macho pursuit. No doubt this had its roots in the belief fostered in boys' schools that being involved in the arts was a sissy thing to do. The natura reaction to this charge was therefore to behave like an out-ofcontrol footballer. There was constant emphasis on their penises in their work and in their conversation. They also drank like drovers who had just hit town after six months in the back country. It was a difficult act to balance, as performing well in bed and drinking like a drover don't work very well together. Another disturbing factor [for these men] was Katherine Mansfield and Frances Hodgkins. The two most creative persons from New Zealand who made it overseas were women.

At the end of the 1950s Fahey was invited to demonstrate oil painting at Auckland Art Gallery. Four or five other women were also invited (she does not name them). 'Pretty quickly I had to understand that it was the men of the gallery who were demonstrating painting. We women were the fall guys. We played intellectual groupies to their already achieved status. I was attempting to paint a bush outside a window. Colin (McCahon) explained to me that I saw only a bush but he saw a cylinder...But at that point I stopped listening.'

This was the national artistic atmosphere in which Pauline Thompson was exhibiting her work for the first time in the late 1950s. Born in 1942, Pauline was a Glendowie schoolgirl and attended Seddon Technical College; from early on she loved poetry and painting. Her first job was as an illustrator for the NZ Herald. She married Ross Ritchie

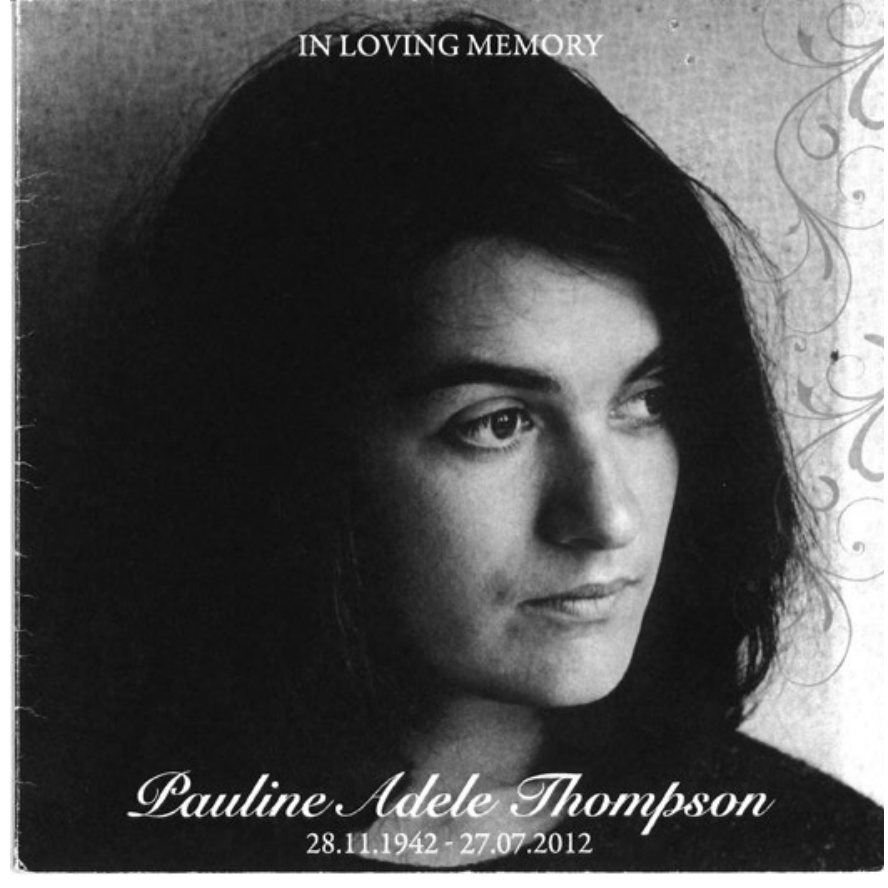

Figure 2. Pauline Thompson portrait 1960s from her funeral order of proceedings

in 1964 (after quitting Elam) and at that time was influenced by the formal abstract style of Mondrian. Her first solo show at 16 was at John Courts (a department store on K Rd in Auckland), followed by a 1959 Palmerston North show, a show at Uptown Gallery in 1964, and at New Vision Gallery in 1965 with Jeff Macklin. In 1966 she had a solo show at New Vision, in 1967 she was part of 'Ten Years of New Zealand Painting' at Auckland City Art Gallery, and in 1969 herself, Ross Ritchie and David Armitage were shown at Barry Lett Gallery. In 1971 she had a show with Ross and Neil Dougan at Mollers Gallery, and in 1973 she was part of a group show at Remuera's Osborne Gallery. This extensive list of exhibitions demonstrates that during the 1960s and 1970s she was being regularly shown in prestigious gallery spaces with other 'up and coming' (often male) artists.

During the 1970s, artist Jane Zusters was attending Art School in Christchurch, where she said that the 'dominant modernist ideology of art for art's sake espoused by Clement Greenberg' was the accepted doctrine. This meant that the art some women were creating which was inspired by investigating their own sense of self and identity was not well received. Often inspired by feminist artists from overseas such 
as Judy Chicago and informed by local knowledge and experience of pro-abortion, anti-Vietnam protests, demonstrations for Māori, gay, and lesbian rights, their work was resisted by the art establishment, and therefore was considered unacceptable to many art gallery and art school spaces. In response to this situation, the Women's Gallery was created in 1979, intentionally and exclusively showing women's work. One year after it opened, Neil Rowe wrote in a review of a Women's Gallery (Wellington) show for the Evening Post:

a gallery ... that is so determined to show art that serves its own polemical ends has less to do with art than it has with politics and a form of therapy for disgruntled ladies ... There is no such thing as 'women's art', or 'men's' art - there is just art which remains, in my definition, the ultimate expression of the individual regardless of sex or political persuasion.

At this time Pauline Thompson probably agreed with Neil Rowe's view. Seven years after this review of the Women's gallery Wellington show, she said: 'I don't think art has any sex. I think the spirit is sexless. I am very influenced by men such as Goya and Velázquez, who painted the dark side of things....' Yet in the very same interview she described her struggles to retain her confidence as a woman artist while raising children, particularly since her husband Ross Ritchie told her she was a 'failed painter'.

I grew up as a contemporary of Pauline Thompson's children in the same neighbourhood, and due to this connection was a model in the early 2000s for Pauline's series 'Under the Horizon', which was exhibited in New Zealand and later Norfolk Island for the Mutiny of the Bounty $150^{\text {th }}$ anniversary celebrations. 'Under the Horizon' included a series of paintings of Tahitian women associated with Pitcairn Island. Pauline would tell me about being a painter while she sketched me, and we had a number of conversations during this period about art, feminism, and the critical reception of her work.

The stories of the women of the Bounty were of interest to Pauline. She wrote her version of the Pitcairn Island history in a letter two years before she died:

'Mainmast' was the Bounty men's nickname for Mauatua, daughter of Tu, the paramount chief of Tahiti in 1789. Mauatua was $6 \mathrm{ft}$ tall and the wife of Fletcher Christian, leader of the Bounty mutiny on Apri 28 1789. Following quarrels over women and land on Pitcairn Is,
Fletcher was shot as he worked in his kumara patch on $3^{\text {rd }}$ October 1793. During that day Mainmast began labour with their $3^{\text {rd }}$ child, Mary, and others on the island supposed the groans of the fatally wounded Fletcher to be the groans of the labouring Mainmast. Mary Christian never married and was known as the 'The Maid of the West'. She is buried on Norfolk Island, next to my great-greatgreat grandmother Dorothy Young. 'Mainmast' is my great-greatgreat-great-grandmother on my mother's father's side'.

Pauline was extremely interested in the stories of the Mutiny of the Bounty because of her ancestral connection, but for other reasons too. She was well aware that the Europeans on the Bounty did not always treat the Tahitians as equals. She described in other correspondence how the white men did not give land to the Tahitian men at Pitcairn. Of the series 'The Women' which was shown within the collection 'Under the Horizon, Seven Paintings by Pauline Thompson' she said that the

...turbulent and violent early years of Pitcairn ended in the late 1790s with the execution of Quintal and the suicide of McCoy. Young died in 1800 of a lung complaint, leaving Adams the only adult male on the island. By his own account he was for some years often intoxicated, so much of the work and decision making came to be done by the women. When in November 1838 Captain Elliot of the "Fly" ratified Pitcairn's laws and carried to London the community's wish to join the British Empire, he noted that Pitcairn men and women had equal voting rights and added that this had been in effect for many years.

While she was sketching Pauline would tell me stories of Mauatua and talk about her views and frustration about the contemporary New Zealand art scene. By the early 2000s, her views on sex, gender and art had changed considerably from the 1988 interview I previously quoted. It is also worth bearing in mind that Pauline spoke to me as a friend, and although she encouraged me to write about NZ women artists, she was not recording her views formally with me for that purpose. Pauline believed by this time that New Zealand women artists had not had their story told in the way men's art histories had been written, and that there was a further women's art history which needed to be written and shared. She unpacked some of the details known to others about her public life recorded in exhibition catalogues and biographical pieces (such as those from Megan Corbett quoted previously) and she provided 


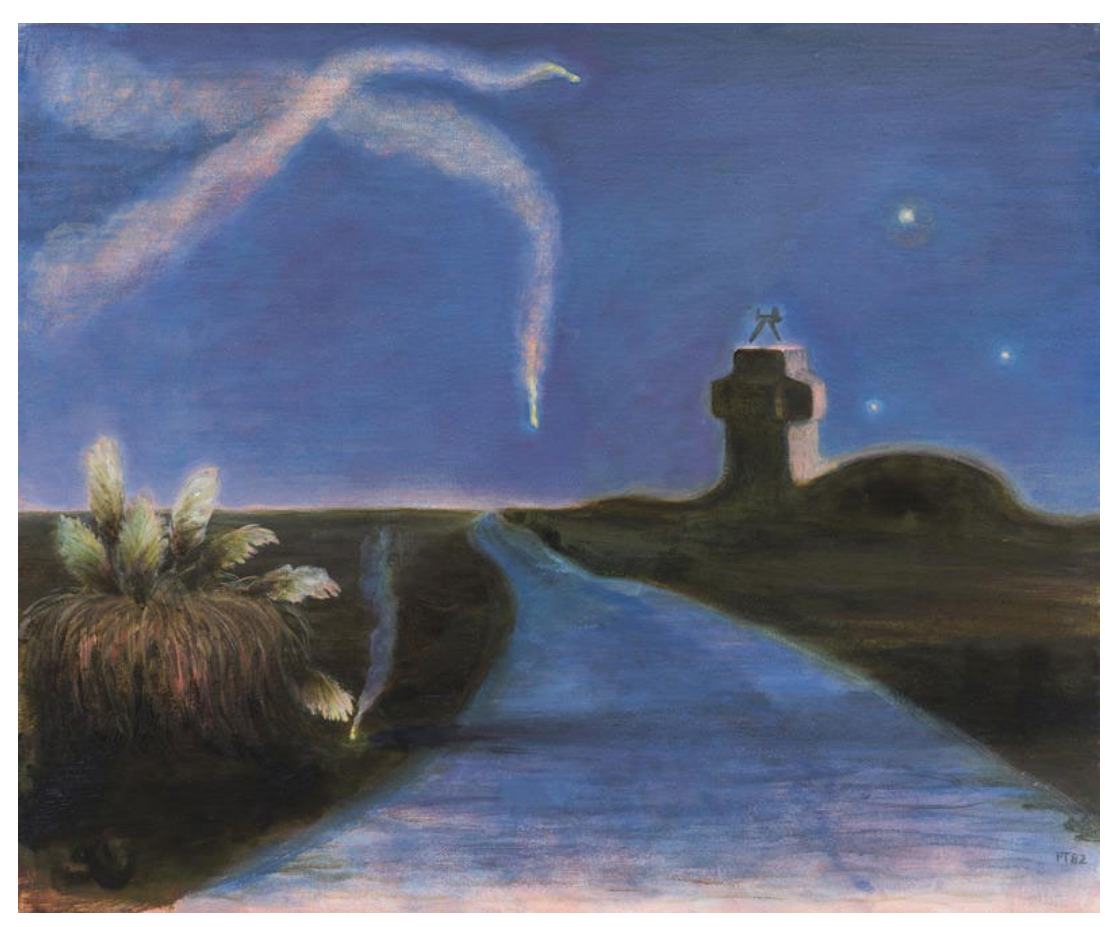

Figure 3. Pauline Thompson, 'Auckland View: Central Police Station, Guy Fawkes Night II' (1982 $505 \times 610 \mathrm{~mm}$, Collection of Auckland Art Gallery, reproduced with permission.

intriguing glimpses into her experiences as a Pacific/Scots/Pākehā woman artist working in Aotearoa over five decades.

Art critic Anne Kirker wrote in 1993 that Pauline's 'small works' of 'the urban environment' are painted with such sensuous delight and transient light conditions' that 'simple rhythmical shapes set in open spaces' create 'an atmosphere laden with symbolic potential'. Kirker's publication on 150 years of New Zealand women painters, like the Women's Picture Book (1988) publication before it, quoted Pauline directly, unlike other articles written previously or subsequently, and therefore provided her perspective on her paintings in her own voice, concurrently destroying some myths which had circulated regarding her biography. For example, where Gordon H Brown stated in a 1983 piece on a Pauline Thompson May/June exhibition at the Denis Cohn Gallery that catering 'to the needs of a young family...during the nineteen-seventies' meant that Pauline's 'creation of artistic work was considerably curtailed over the next several years', Kirker quoted Pauline explaining that during the $1972-9$ period she was painting sexual organic forms, cells, sperm, and ova, a 'less fashionable iconography' which corresponded partly to the artist's involvement with the Sufi religion. In this interview Pauline said; 'I am popularly supposed to have confined my activities to child-rearing. The plain fact is that these cyclic symbols and cellular forms were not greeted with any delight by dealers who saw them. During these "inactive" years I made about 30 paintings and hundreds of drawings'.

In the aforementioned 1983 Gordon H Brown review in Art NZ, Brown is clearly impressed by the works, praising Pauline as a 'skilled, sensitive painter', but in the same breath says that her work is usually metaphysical; often 'overshadowed by a particular mode of feeling'. It is the 'very absence of such visionary or supernatural aspects [in this exhibition] that allows the viewer to concentrate on what it is that these paintings possess as paintings'. There is an echo in this passage of the Clement Greenberg philosophy 'art for arts sake' Jane Zusters previously described.

As you may recall, Megan Corbett had described Pauline's art changing to a more 'serious' and 'metaphysical' style after her relationship break up in the 1980s. She does not mention that this was in the mid-1980s when the children were still quite young (early to midteens). Pauline was suddenly alone facing the dilemma of the mother left to care for children, with very little money. Pauline told me at this time she heard a performance on RNZ National of a 1974 play called 'Judgement' by Barry Collins, which elaborates upon the bare details of an historical incident of cannibalism in WWII.

The play portrays a group of Russian soldiers trapped in a basement in Poland, eventually drawing straws to see who will be eaten. When they are finally rescued, the remaining soldiers are executed for cannibalism. Pauline said she stayed up for days and nights painting the series which would become known as 'Judgement I' (1987). She also painted a second series, 'Judgement II' (1989) which is held by Auckland Art Gallery.

Pauline's stories of her own experiences, her response to the play 'Judgement' (which she said was rage and adrenaline filled) at the ending of her marriage, and the differing accounts of Pauline's output during the time her children were small demonstrates Pauline's own awareness of the judgements being made upon her work, her passion and determination, and her ability to continue on regardless, to have enough faith in herself and her instincts as an artist to continue her practice. 
As we have seen, the Women's Gallery was specifically founded as an alternative gallery space for women's art which did not fit the dominant modernist ideology. That same group became the Spiral Collective, publishing books for women who were not able to find publishers - J.C. Sturm's first collection of poetry, Keri Hulme's 'The Bone People' (both in 1983) and their own 'A Women's Picture Book: 25 Women Artists of Aotearoa New Zealand' in 1988., Although not involved with the Women's Gallery particularly, Pauline was interviewed for the latter publication, in which she is quoted as saying that art has no sex. But she did recognise that an artists' experience is gendered. When asked if it made any difference to the 'seriousness with which you take yourself, that you have a husband who's a painter? Has there been a struggle for you to be painters?' Her reply was very brief - 'At times, yes.' The interviewer then says somewhat provocatively: 'You don't want to talk about it. It's very interesting, no-one will talk about it'. Pauline responds:

Is that right? The husbands deny it, that's why...After I had kids, because I lost concentration I think he thought I was an utter zombie. Because you're wrapped up in the kids and things like potty training, they find that after a day out in the wide world it's a bit much. But that's also what they expect, and anything else is a funny little hobby and any ideas that you've got are quaint little ideas. That, on top of lack of sleep and physical exhaustion, can really undermine your self-image and self-confidence. I think a lot of women could just stop. Before I started painting again I actually left Ross for about three months.

So, did Pauline's painting change after the (final) break up of her relationship? And should the change be defined by the end of that relationship? Or was her work being understood through a (male) gendered lens which made assumptions about her work, her abilities, and her paintings in relation to her husband and children? The fact that her style had been described in a 'pop art idiom in conjunction with her husband Ross Ritchie' is in itself problematic. Pauline had a separate art practice from her husband's (although we've seen that they were shown in several exhibitions and in the 1969 Brown and Keith publication alongside each other). But they had distinct and separate art practices. It is just as likely that Pauline, like many women in the 1970s and 1980s in New Zealand was becoming more aware of a feminist conversation which suggested life could be organised differently, that men might share the household and childcare duties equitably, allowing women the time and space to create in a way that had not previously been regarded as acceptable.

The term 'metaphysical' recurs in art critics' descriptions of Pauline's art; along with comments that her paintings are effused with 'emotion', 'atmosphere' and 'feeling'. For example, in Warwick Brown's '100 New Zealand Paintings' (1995 Godwit), (in which 28 of the paintings are by women) he opens by stating that:

The luminous, almost abstract atmospheric painting of J.M.W.Turner stands at the beginning of the development of modernism. It is therefore interesting to see it being used in the 1990s by a senior contemporary painter, particularly one who came to notice in the 1960 s as the maker of some of the few pop paintings done in New Zealand in that decade.

Brown describes Pauline's career shifts and changes through to 1985, saying her work changed 'towards a strange mix of lyricism and high drama, a blend of Goya and Turner. Her colours changed to yellows, reds, and dark browns and greens. In glowing fields of colour, scenes of death, cannibalism and sickness were vividly, harrowingly portrayed. Subjects included Mother Aubert's care of lepers, Russian prisoners surviving two months without food or water, and the histories of the Bounty mutineers and Norfolk Island'. The review then abruptly halts (representing 100 paintings means you only have a page for each which is a challenge) but the strongest opinion expressed by the author is through the work which he has chosen to represent Pauline's oeuvre a painting from 1985, 'Rangitoto View Guy Fawkes Night', before her (supposed) shift to a 'strange mix' which he appears to disapprove of.

Gregory O'Brien, who included a painting by Pauline in the 2000 exhibition and book 'Parihaka: The Art of Passive Resistance' considers this metaphysical aspect of her work in a more positive light, stating that Pauline's:

Metaphysical paintings of the early 1980s established her as one of New Zealand's foremost narrative painters. A direct descendant of one of the Bounty mutineers and his Tahitian wife, Thompson has explored her links to Norfolk Island and Pitcairn Island.

O'Brien, who has written about Pauline's work in various contexts and corresponded and communicated with her, appeared to understand her 
as she saw herself - as a painter very much engaged by Oceania, the Pacific, and the country in which she lived. She was interested in the indigenous experience, in the non-European versions of the stories of these places, in women's experience of these histories, and in spirituality and the paintings she created reflecting these interests.

In the mid-1980s Pauline read 'Petticoat Pioneers' in which there was, she said 'one article...about this eccentric nun who swam across rivers with all her clothes on her head. It seemed so bizarre... so I went and got a book on her and found she was ten times as bizarre as it showed in the other book, an incredible woman. I thought she was somebody who symbolized, if you like, one who looks after those parts of ourselves which are the hidden parts, the darker parts, the part that's not out in the open, not out in the marketplace: the role that's often taken by or symbolized by women, or children, or the dark races, religion, anything on that side. The illogical rather than the logical, unconscious rather than the conscious'. Pauline also later read Jessie Munro's biography of Suzanne Aubert which described Aubert's experience struggling against the work of the bishops who were jealous of her success, her personal wealth and her autonomy. Eventually as a woman in her eighties Suzanne went to Rome for six years to secure the independence of the sisters of the Home of Compassion to ensure it could not be harmed or dismantled by the Bishops in New Zealand.

Pauline's work from the mid-1980s onwards followed these strands: the illogical, that which is not aimed for 'the marketplace'. She painted or drew Suzanne Aubert many times and gave some of the resulting prints and paintings to the sisters at the Home of

Compassion in Island Bay. She corresponded with the sisters thereafter, often describing and explaining the origins of a work. The Home of Compassion Archive holds a number of her works (copies and some originals) and correspondence. She wrote:

[my work] is a process by which, beneath different series, persistent themes such as death and rebirth occur, and interweave my work as does Mother Aubert.

Pauline depicted the Bounty descendants spiritually, almost biblically at times, but explained to the sisters:

My depictions are not intended as a deification of my forbears, o indeed of Mother Aubert, but more (I hope), as a glimpse of the immanence of God in the world, through all manifestations, even little dogs and birds as well as great whales.

In a 1991 review in Art NZ, Wendy Vaigra said:

Pauline Thompson is working through narratives derived from other genres: a play, a novel, a biography, and oral and written histories of Norfolk and Pitcairn Islands. She is using religious symbolisms in a complex way, along with art historical references as a framing device...Foucault's concept of the 'insurrection of subjugated knowledges' is relevant to these paintings that so powerfully resist the conventional readings of the majority culture.

In response to a description by Sister Bernadette of whales and seaturtles she had seen while working in Fiji, Pauline said - 'The world is full of never-imagined beauty, light-in-darkness, and never-ending surprise.'

By 2000 , art critics were perhaps more open to Pauline's work, with Keith Stewart describing her as 'rare not just in her ability to paint the unseeable, to give us images steeped in passion, but in her unequivocal approach to a subject which is at odds with the nagging intellectualism which surrounds the world of fine art'. He described the difficulties of the art world responding to 'emotion' in art theory, and said that Pauline had 'little time for fripperies of fashion, or intellectual art banter', and was therefore 'something of an outcast, at least in the contemporary art marketplace where rational painting, especially as a form of calculated investment, is successful painting'. Stewart appeared sympathetic to Pauline's work, but simultaneously supported the male dominant ideology of the 1970s art schools and gallery world when he described Pauline's home in an Auckland suburb which he said:

makes the point that hers is a gritty spirit woven from a life no more or less ordinary than that which most people experience. Her insights are drafted from this life of shopping and washing, preparing meals, raising children, paying a mortgage, gardening, holding all those strands together to the end of each week, taking pleasure where you can find it, and inspiration.

Most of this is absolutely true - Pauline lived at the time in a working class state house street in Birkdale - yet I have never seen a senior contemporary male artist described in such terms. Stewart is using 
coded, gendered language- and in 2000 when he is writing this, her kids have long left home. Yet Stewart pursued the myth of the domestic goddess, the mother, the struggling artist awash with housewifely detritus, as if the 1975 passage with which I opened this presentation where the author feels the need to protest that the women artists 'are not Sunday painters, dabbling in art in the midst of domestic duties, but professionals, professionally trained and devoting their life to their art' was written only yesterday.

Pauline's life and work proved that one could be both a professional painter, devoting ones life to their art, and be a mother, not an 'ardent spinster'. Yet to the end of her life, some art critics pursued descriptions of her in gendered terms, in a way which they did not describe male senior contemporary artists of her generation - including her ex-husband Ross Ritchie, who told her all those years ago that she was a 'failed painter'. She certainly never became wealthy in the sense of the art marketplace, she never had the retrospective which would have put her work in context over time and allowed her to discuss the shifts and changes with hindsight, but she is represented in most major galleries in New Zealand and Australia.

In 2012, Pauline was dying of cancer. John Kelly, her friend and my father, took her to Monte Cecilia Pah Homestead where the James Wallace Art Collection is held and exhibited. They went to see one of her paintings, of Mother Aubert opening the door to a stranger. Pauline was upset to see the label on it was incorrect. It simply said a woman opening a door to a stranger. Dad went to tell the docent, while Pauline sat down by the painting and began to explain to anyone who came to look at it, that it was actually Suzanne Aubert, Mother Superior of the Home of Compassion, who was taught to respect everyone, no matter their station in life, and to open the door even to a beggar for food, just as you would Jesus himself, with a curtsey and a warm greeting. By the time they left that day the label had been corrected.

This story personifies for me Pauline's nature and her work she believed passionately in her own work and the importance of representing it, of telling the stories of women, and indigenous peoples. The 'unofficial histories', as Wendy Vaigro said; Pauline Thompson presented 'another history, told from the point of view of the losers, the silenced ones'. Often those silenced ones are women painters like Pauline, who to the end of her life insisted on telling her own story, her own way, within the art gallery itself, and through the life she created as an artist and in the discussions she had about her work. But it also should be remembered, that through the struggle and challenges,

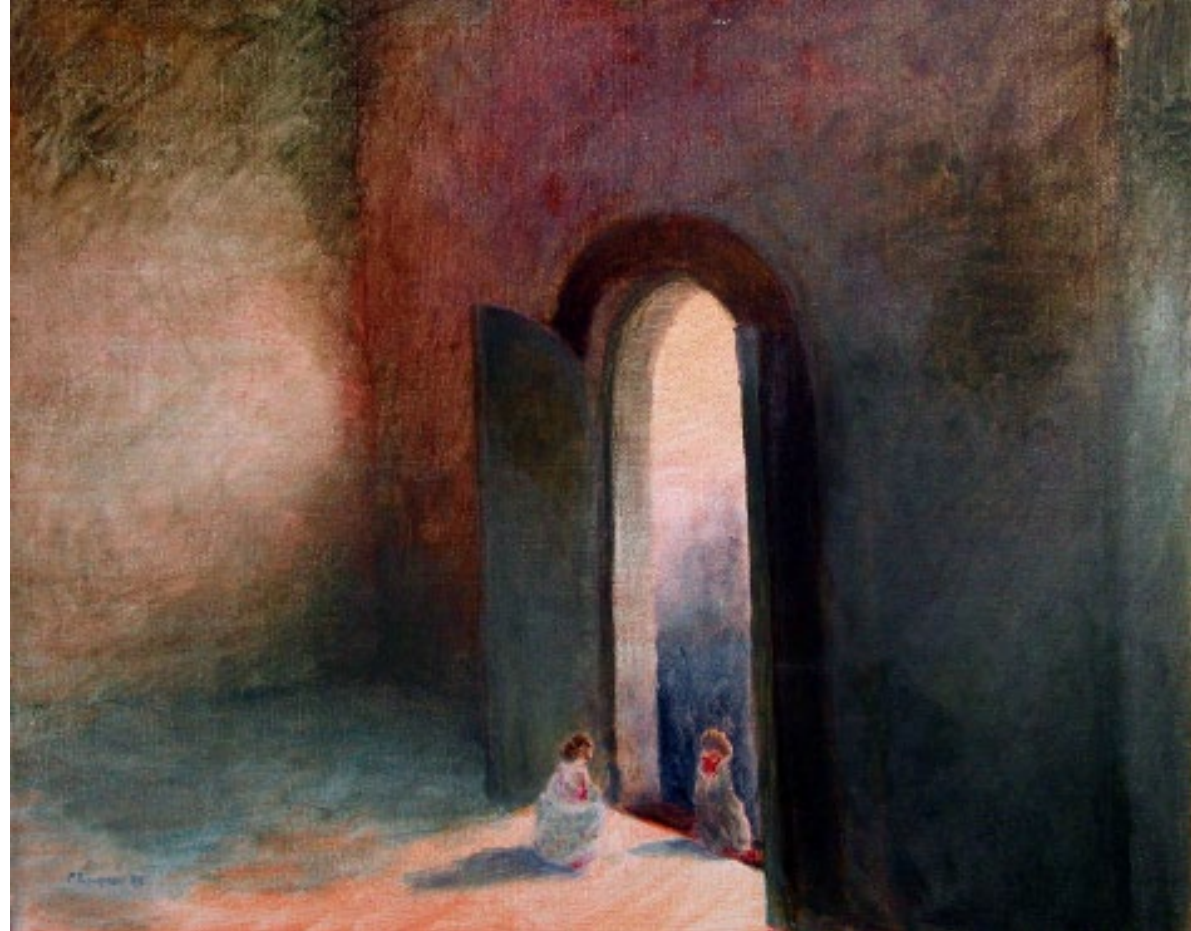

Figure 4. Pauline Thompson, 'Suzanne Aubert giving alms to the poor' (1985) 610 x 760mm, James Wallace Collection, reproduced with permission http://collection.wallaceartstrust.org.nz/collection/ search.do?view=detail \&page $=1$ \&id $=15368 \& \mathrm{db}=0$ bject 
Pauline Thompson always recognized and delighted in beauty; only two years before her death she was telling the sisters from the Home of Compassion that 'The world is full of never-imagined beauty, light-indarkness, and never-ending surprise.'

In the 1988 Women's Gallery publication, Pauline was asked what gave her confidence to keep painting when she wasn't being exhibited and her husband had told her she was a failed painter. She replied:

Well I suppose I just got terribly desperate, I got my back to the wall...I realised I was a lot stronger than I was giving myself credit for being and I'd been covering this up by my lack of self-confidence and negative self-image - which was just as stupid as if it were an overly good image like a lot of men.

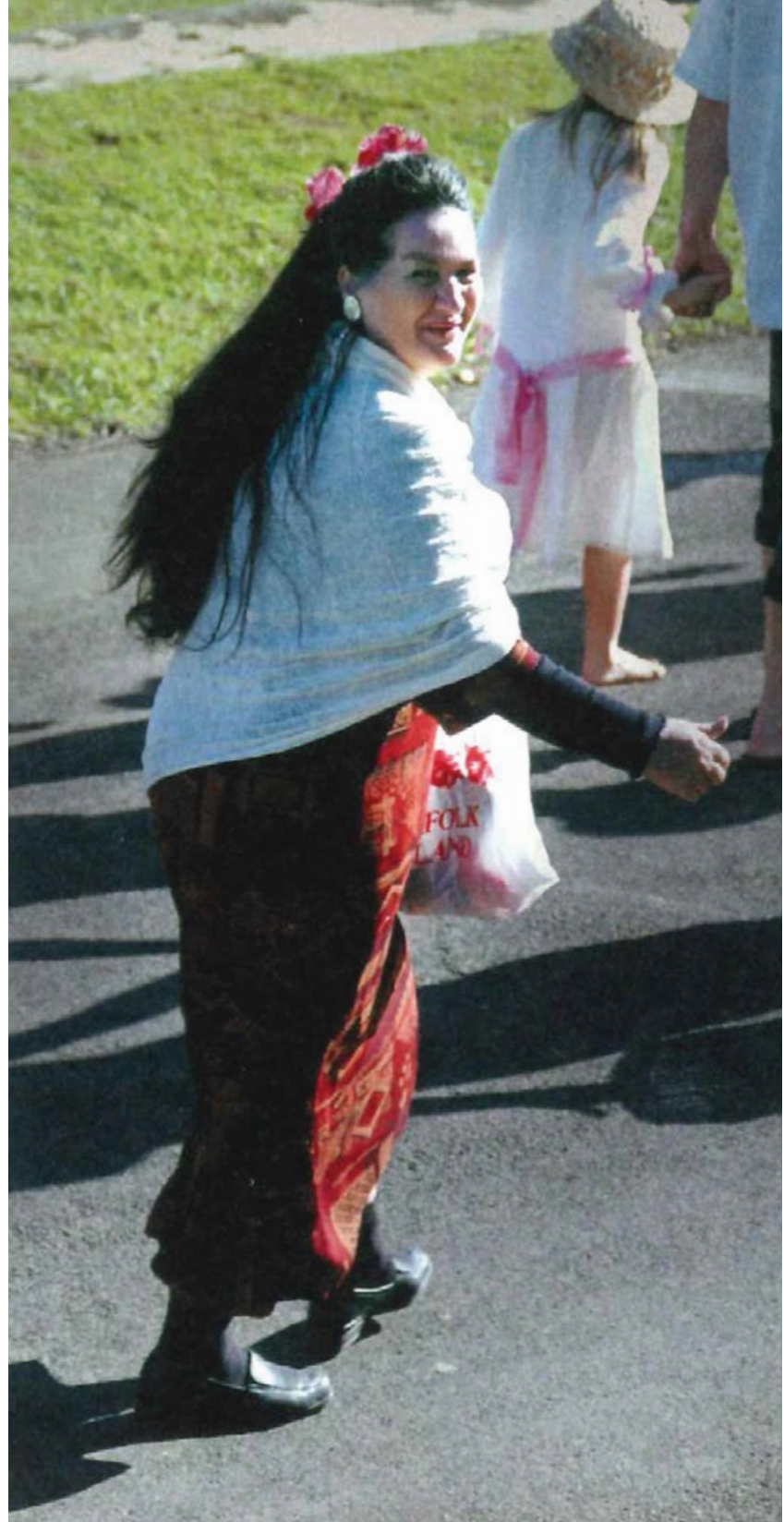

Figure 5. Pauline Thompson at the Bounty celebrations, Norfolk Island, (2007) 


\section{REFERENCES}

\section{ARCHIVES}

Home of Compassion archives, Island Bay Wellington, Pauline Thompson 20090040010 (2001-2009).

Alexander Turnbull Library, Spiral Collective/ Women's Gallery Collection 91-023-3/10

Pauline Thompson

\section{PERIODICALS AND ONLINE} Ardor Gallery of Contemporary Art,' The Four Seasons, paintings of Pauline Thompson'. Exhibition Catalogue, 2003

Brown, Gordon H. 'Extending the Limits of the Visible'. Art New Zealand no.29 Summer 1983

Evans, Marian. 'Spiral Collective 1975 - from 'Women Together: A History of Women's Organisations' (1993) NZ History.govt.nz

Vaigro, Wendy. 'Narratives of the Heart: Recent Paintings by Pauline Thompson' Art New Zealand no.58 Winter 1991

\section{BOOKS}

Brown, Gordon H. and Hamish Keith. New Zealand Painting: an introduction. Collins, London, 1969.

Brown, Warwick. 100 New Zealand Paintings. Godwit, 1995

Brown, Warwick. Another 100 New Zealand Artists. Godwit, 1996.

Evans, Marian; Lonie, Bridie; Lloyd, Tilly (eds). A Women's Picture Book: 25 Women Artists of Aotearoa (New Zealand). GP Books, 1988.

Fahey, Jacqueline. Something for the Birds. Auckland University Press, 2012 (first edition 2006).

Kirker, Anne. New Zealand Women Artists; A Survey of 150 Years. Reed Methuen, Australia 1993.

McGregor, Miriam. Petticoat Pioneers: North Island Women of the Colonial Era. A.H. and A.W.Reed, Wellington, 1973.

Te Miringa Hohaia, Gregory O'Brien, Lara Strongman (eds) Parihaka: The Art of Passive Resistance. City Gallery Wellington, Victoria University Press, 2001

Stewart, Keith. The Food of Art: New Zealand Painters and their food. Craig Potton Publishing, 2000.

\section{END NOTES}

1. Peter Fitzsimons, Mutiny on the Bounty. Hachette,

2. Auckland Art Gallery 1975 NZ Women Painters Catalogue https://www.aucklandartgallery com/page/new-zealand-s-women-painters Accessed 12 January 2020.

3. Kirker, Anne. New Zealand Women Artists; $A$ Survey of 150 Years. Reed Methuen, Australia 1993

4. Stewart, Keith. The Food of Art: New Zealand Painters and their food. Craig Potton Publishing 2000 pp 114-116.

5. Te Miringa Hohaia, Gregory O'Brien, Lara Strongman (eds) Parihaka: The Art of Passive Resistance. City Gallery Wellington, Victoria University Press, 2001, p 165.

6. Megan Corbett, 'Pauline Thompson: Tuki \& Huru Suite - Banner Paintings'. Whangarei Art Museum Newsletter Dec 1997 no.5

7. Megan Corbett, 'Pauline Thompson: Tuki \& Huru Suite - Banner Paintings'. Whangarei Art Museum Newsletter Dec 1997 no. 5

8. Megan Corbett, 'Pauline Thompson: Tuki \& Huru Suite - Banner Paintings'. Whangarei Art Museum Newsletter Dec 1997 no.5

9. Personal correspondence with author, 7 February 2000.

10. Jacqueline Fahey, Something for the Birds Auckland University Press 2006, 2012, p.196

11. Jacqueline Fahey, Something for the Birds, Auckland University Press 2006, 2012, p.138,139

12. Vanya Lowry, 'Pauline Thompson', Metro Magazine, September 1983 no. 27 pp 26,27.

13. Judy Chicago, Through the Flower: My struggle as a woman artist, Penguin Books 1975

14. Jane Zusters, Fabulous Feminism Exhibition Catalogue $2016 \mathrm{http}: / / \mathrm{www}$.newzealandpainting co.nz/2016/08/fabulous-feminism/

15. Neil Rowe, review of women's Gallery (Wellington) show (Evening Post Feb 2. 1980) https://www.art-newzealand.com/lssues21to30/ replacing.htm

16. Evans, Marian; Lonie, Bridie; Lloyd, Tilly (eds). A Women's Picture Book: 25 Women Artists of Aotearoa (New Zealand). GP Books, 1988 p.31.
17. Personal correspondence with author 7 February 2000

18. Pauline Thompson to Sister Bernadette of the Home of Compassion, 2010. Archives of the Home of Compassion 20090040010

9. Pauline Thompson, Under the Horizon: Seven Paintings by Pauline Thompson. An Exhibition Marking the 150th Anniversary of the June 8 Landing of the Pitcairners on Norfolk Island, 1856, Various venues, 2006

20. Kirker, Anne. New Zealand Women Artists; $A$ Survey of 150 Years. Reed Methuen, Australia, 1993 p.203.

21. Gordon $\mathrm{H}$ Brown, 'Extending the Limits of the Visible', Art New Zealand no.29 Summer 1983 p. 25 22. Letter to Anne Kirker from Pauline Thompson 22 March 1985, Artists File National Art Gallery, Wellington quoted in Kirker, Anne. New Zealand Women Artists; A Survey of 150 Years. Reed Methuen, Australia, 1993 p.202.

23. Gordon H Brown, 'Extending the Limits of the Visible', Art New Zealand n.29 Summer 1983, p.24.

24. Barry Collins' 'Judgement' was written in 1974. Two 'Judgement' series were created by Pauline based on this play; one Judgement I (1987) which was exhibited at Auckland Art Gallery and consists of 13 paintings, and Judgement 11 (1989) which is part of the Auckland Art Gallery collection. Viewing copy online: Pauline Thompson 'The First Cannibal Feast Begins - Panel 3 from Judgement I' (1987) $610 \times 510 \mathrm{~mm}$, Oil on canvas, https://www. aucklandartgallery.com/explore-art-and-ideas/ artwork/7197/judgemen

25.

26. 'Judgement I' was sold to a private and anonymous buyer in the early 2000s (Persona correspondence, Pauline Thompson, February 2002).

27. Evans, Marian; Lonie, Bridie; Lloyd, Tilly (eds). A Women's Picture Book: 25 Women Artists of Aotearoa (New Zealand). GP Books, 1988

28. Te Kare Papuni/Jacqui Baxter/J.C.Sturm's 'The House of the Talking Cat' was published in 1983 in the same year as Keri Hulme's 'The Bone People' which won the internationally recognised Booker Prize. He Whakamaumahara Wellington City Libraries, 5 March 2010 https://issuu.com/ 
wellingtoncitylibraries/docs/jacquie_baxter-jc _ sturm_biography?e=37768242/75276900

29. Evans, Marian; Lonie, Bridie; Lloyd, Tilly (eds). A Women's Picture Book: 25 Women Artists of Aotearoa (New Zealand). GP Books, 1988, p 30

30. Pauline was not the only woman experiencing these challenges to her art process and sense of self as a woman expected to perform gendered tasks to fit a gendered model of heterosexual households. Te Papa holds a collection of interviews with 50 women artists created in the 1980s who 'represented the burgeoning women's art movement in New Zealand', affilited with the Association of Women Artists. This colloction Association of Women Artists. This collection was made possible by artist, teacher, and feminist Vivian Lynne...who volunteered to collect those interviews. Lynne herself 'began questioning the roles women were expected to play in society [during the 1960s] as wives and mothers, and in the art world, as secondary to their male peers'. https://collections. tepapa.govt.nz/object/189

31. In 1997 in an exhibition catalogue for a solo exhibition of Pauline's work at Whangare Art Gallery, Megan Corbett wrote that Thompson 'worked in a Pop Art idiom in conjunction with her 'wurkery a Pop Ant idiom in conjun husband. After the break up of this relationship her work took a more serious and metaphysical aspect Megan Corbett, 'Pauline Thompson: Tuki \& Huru Suite - Banner Paintings'. Whangarei Art Museum newsletter Dec 1997 no.5

32. For example Stewart, Keith. The Food of Art: New Zealand Painters and their food. Craig Potton Publishing, 2000; Brown, Warwick. 100 New Zealand Paintings. Godwit, 1995; Brown, Warwick. Another 100 New Zealand Artists. Godwit, 1996.

33. Warwick Brown, 100 New Zealand Paintings, Godwit, 1995, p. 89.

34. In his follow up book for 1996 'Another 100 New Zealand Painters', 29 of the painters are women. Brown, Warwick. Another 100 New Zealand Artists. Godwit, 1996.

35. Te Miringa Hohaia, Gregory O'Brien, Lara Strongman (eds) Parihaka: The Art of Passive Resistance. City Gallery Wellington, Victoria University Press, 2001, p 165.

36. O'Brien's newest publication A/ways Song in the Water: An Oceanic Sketchbook, Gregory O'Brien AUP, 2019 has a section on Pauline's work.
37. Miriam Macgregor, Petticoat Pioneers. North Island Women of the Colonial Era, Book One A.H.and A.W.Reed, Wellington and Christchurch, first published 1973, 1978 (second edition), 1981 (third edition).

38. Evans, Marian; Lonie, Bridie; Lloyd, Tilly (eds). A Women's Picture Book: 25 Women Artists of Aotearoa (New Zealand) GP Books, 1988. p.34.

$$
\text { 39. Jessie Munro, The Story of Suzanne Aubert, }
$$
Bridget Williams Books, 1996 (first edition).

40. Letter to Sister Josephine 28 March 2010 from Pauline Thompson, Anne McLean Dr, Bayview, North Shore Auckland in Home of Compassion archives, Island Bay Wellington, Pauline Thompson 20090040010 (2001-2009).

41. Pauline Thompson to Sr Josephine Gorman and Sisters at the Home of Compassion, 28 March 2010, Home of Compassion Archive Island Bay Wellington, Pauline Thompson 20090040010 (2001-2009).

42. Wendy Vaigra, 'Narratives of the Heart: Recent Paintings by Pauline Thompson', Art New Zealand No. 59 Winter 1991 p.71.

43. Letter to Sister Josephine 28 March 2010 from Pauline Thompson, Anne McLean Dr, Bayview, North Shore Auckland, Home of Compassion Archive Island Bay Wellington, Pauline Thompson 20090040010 (2001-2009).

44. Keith Stewart, The Food of Art; New Zealand Painters and their food, Craig Potton, 2000 p.114

45. Stewart, K. ibid p.114

46. Stewart, Keith, p.116

47. John Kelly, correspondence with author, 2 June 2017

48. Wendy Vaigro, 'Narratives of the Heart: Recent Paintings by Pauline Thompson' Art New Zealand No.59 Winter 1991, p.71

49. Evans, Marian; Lonie, Bridie; Lloyd, Tilly (eds). A Women's Picture Book: 25 Women Artists of Aotearoa (New Zealand). GP Books, 1988, p.31

\section{Self Help, Sunlight and a Modern Chair: Considering Auckland's historic signage as a heritage object}

Caroline Powley

Cities are an ever-changing space, filled with commerce and community. Signage plays a strong role in the visual narrative of the urban environment. It creates a constant visual hum, a street level monologue of promotion, identification and direction. Commercial signs are designed to serve and improve business. So, what role could an old, fading or non-functioning piece of signage possibly play in our neoliberal capitalist society? From a designer's perspective, there's a lot to like - the craftsmanship, the idiosyncrasies of a hand-generated piece of typography, the sense of nostalgia for a time before globalisation and brand guidelines took over. Looking at historic signs from a broader context they also represent an "intricate urban history." 1 They speak of the changing face of commercial enterprise, social values and cultural expression. Even when they no longer serve their original semantic role of commercial promotion, they "accumulate rich layers of meaning. They no longer merely advertise, they are valued in and of themselves. They become icons." 2 The semiotic function of an historic sign shifts to a new role-signifying notions of survival, continuity and loss. They also feed into our complex personal narratives of place, identity and community. ${ }^{3}$ These multiple and interwoven values can form the cultural significance of historic signs. Despite this recognisable value, historic signage tends to fall through the gaps of heritage practice and legislation in New Zealand. This paper offers a set of case studies that represent a range of possible outcomes for historic signs, when they exist outside a system of heritage management. I propose six categories for framing the case studies: remain, repair, regenerate, relocate, replace and remove. These examples are combined with a broader reflection on the value of historic signage and an overview of relevant heritage practice in New Zealand. The intention is to encourage reflection on the possible heritage significance of historic signage and our current approach to assessment, scheduling and conservation.

Keywords: \#signage \#heritage \#historic places \#preservation \#cultural value 